\title{
A study of growth inhibitory factor in rabbit mandibular condylar cartilage
}

\author{
Shin Hasegawa \\ Department of Orthodontics, Kanagawa Dental College \\ (Chief: Prof. Yoshii Suzuki) \\ Department of Oral Biochemistry, Kanagawa Dental College \\ 82 Inaoka, Yokosuka, Kanagawa 238 \\ (Chief : Prof. Shigeru Saito)
}

[Accepted for publication : November 26, 1983]

Key words : growth inhibitory factor / mandibular condylar cartilage / chondrocyte proliferation / cell culture

\begin{abstract}
Since the endochondral bone growth of the mandible is a most important mechanism in the field of craniofacial growth and development, an investigation which examined the acid extracts from cartilage tissues in vitro culture system was done in order to explore the growth regulating factors in mandibular condylar cartilage.

Cultured chondrocytes isolated from young rabbit costal cartilage were used for assay of mandibular condylar cartilage derived factors. Crude acid extract and a chromatographically stparated fraction (F-IV) from the mandibular condyle had an ability to inhibit chondrocyte proliferation in cell culture. An extract from nasal septal cartilage slightly inhibited proliferation of the chondrocytes, where as those from other cartilage, capital cartilage and costal cartilage, did not inhibit the ${ }^{3} \mathrm{H}$-Thymidine incorporation. However, this inhibitory activity was gradually reduced with to subculture progression.

These results suggest that this growth inhibitory factor from mandibular condylar cartilage may have a physiological role in the growth regulating mechanism of this unique cartilage.
\end{abstract}

\section{Introduction}

The mandibular condyle is a site of endochondral ossification which persists throughout life and plays an important part in the preand postnatal growth of the mandible. Studies on the growth potential in the mandibular condylar cartilage have been of greater interest in the characterization of its growth activity compared with those in other cartilage tissues, such as epiphysial cartilage, nasal septal cartilage and synchondrosis ${ }^{1-3)}$. These investigations suggested that the condyle is a site of endochondral ossification which is essential for normal bone growth. On the bases of the experiments of Kosk et al..$^{4,51}$, they suggested that the growth potential of condylar cartilage was less than those of the epiphysial cartilage and the synchondrosis.

Interest in the growth of the condylar cartilage has been shifted to a new question why the condylar cartilage has a uniqueness of lower growth activity compared with other cartilage tissues. In hyperplasia of the condyle, the mandible is enlarged which may be due to the collapse of the mechanism of self control in the condylar cartilage. According to Petrovic et al.$^{6,7)}$, the presence of chondroblasts has a restraining effect on the multiplication of prechondroblasts and such a restraining effect is a cybernetic negative feedback signal, being part of the regulatory system. However, the existence of the growth regulating factor in the mandibular condylar cartilage has not yet been determined at the biochemical level. In order to achieve the degree of control seen in cartilagious mandibular bone growth, one could speculate that a substance which inhibits the cell division might be present.

In order to know if such a cell division inhibitory substance exists, an assay system of rabbit mandibular condylar cartilage derived factor was characterized. In this article, the 
effect of the extracts from rabbit mandibular condylar cartilage, nasal septum, capital cartilage and costal cartilage on the proliferation of the chondrocytes in cell culture was examined. The results in this study strongly suggest the existence of an intrinsic growth regulatory factor of the condylar cartilage.

\section{Materials and Methods}

1) Isolation and Cultivation of Chondrocytes from Costal Cartilage

Activity of a growth regulatory factor was assayed by measuring the stimulation of DNA synthesis in confluent grown monolayers of primary cultures of chondrocytes from the costal cartilage of young male Japanese white rabbits (200-400 $\mathrm{g}$ body weight). The preparation and culture of primary chondrocytes were performed by using a modification of the technique of Suzuki et al. ${ }^{8}$. The fresh costae were removed aseptically and immediately immersed into cold Hank's balanced salt solution (Nissui Pharmaceutical Co., Tokyo). The costae's adherent muscles and perichondrium were stripped as far as possible, and the growing zone of cartilage tissue was separated.

Freshly isolated cartilage tissues were diced into small pieces and incubated with $0.2 \%$ (v/w) Trypsin (Difco Laboratories Inc. Detroit, MC.) in $\mathrm{Mg}^{2+}$ and $\mathrm{Ca}^{2+}$ free phosphate buffered saline (PBS $(-)$, Nissui.) at $37^{\circ} \mathrm{C}$ for 40 minutes. After removal of the trypsin solution, the cartilages were further incubated with $0.2 \%(\mathrm{v} / \mathrm{w})$ clostridial collagenase (Wako Pure Chemical Industries Ltd., Tokyo) in PBS $(-)$ at $37^{\circ} \mathrm{C}$ for 2.5 hours. The chondrocytes were passed through a $153 \mu \mathrm{m}$ stainless sieve to remove debris and undigested cartilage fragments. They were then centrifugated at $1,000 \times \mathrm{g}$ for 5 minutes to remove the collagenase. The cell pellet was washed with fresh Ham's F-12 medium (Nissui) containing $10 \%$ fetal bovine serum (FCS, Flow Laboratiries, McLean, VA), $60 \mathrm{mg} /$ liter kanamycin sulfate (Boeheringer, Manheim, $\mathrm{GmbH}$ ), and then resuspended in the same medium as described above at a concentration of $1.0-1.5 \times 10^{5}$ cells/ $\mathrm{m} l$. The cell viability after enzymatic digestion exceeded $90 \%$ as judged by trypan blue exclusion. The primary chondrocytes were plated into $25 \mathrm{~cm}^{2}$ plastic tissue culture flasks (Falcon, Div. of Becton, Dickinson and Co., Oxnard, CA) and grown for 4 to 8 days at $37^{\circ} \mathrm{C}$. These chondrocyte cultures were used for assessment of the extracts from various cartilage tissues at various stages of subculture period.

2) Extraction of Growth Regulatory Factor from Mandibular Condylar Cartilage

The growth inhibitory factor from the man. dibular condyle was compared with those from three different cartilage tissues; chondroseptum, capital cartilage and costal cartilage. These were removed from seventy-five Japanese white rabbits (body weight $1.5-3.0 \mathrm{~kg}$ ). Each cartilage sample was freed from the muscles and overlying perichondrium and then homogenized in $0.1 \mathrm{M}$ acetic acid utilizing a Polytron homogenizer. The extracts were clarified by centrifugation at $10,000 \times \mathrm{g}$ for 20 minutes. These samples were pooled and used in all subsequent experiments.

The supernatants were subjected to molecular sieve chromatography, using Sephadex G 200 column $(3 \times 100 \mathrm{~cm})$. The column was eluted with $0.1 \mathrm{M}$ acetic acid at a flow rate of $15.0 \mathrm{~m} l / \mathrm{hr}$ and $7.0 \mathrm{~m} l$ fractions were then collected. The fractions were monitored for absorbance at $280 \mathrm{~nm}$ and the fractions containing proteins were lyophilized and weighed. The lyophilized materials were dissolved in Ham's F-12 medium as described above. Each sample was tested for its ability to stimulate DNA synthesis in confluent cultures of chondrocytes. Unless otherwise indicated, primary cultures were used.

3) Sodium Dodecyl Sulfate Polyacrylamide Gel Electrophoresis (SDS-PAGE)

Polyacrylamide gel disc electrophoresis was used for the analysis of the extracts from mandibular condyle using $5 \%$ sodium dodecyl sulfate. Electrophoresis was conducted for about 5 hours at room temperature at constant current of 6-7 mA/tube. For molecular weight determination, $2.5 \mu \mathrm{g}$ of standards of known molecular weight were used (Pharmacia Fine Chemicals, Uppsala, Sweden). The gels were stained in a $5 \%$ coommasie blue solution for 1 hour and destained by washing in a $7 \%$ acetic acid solution.

4) Assay for Chondrocytes Proliferation 
Chondrocytes were trypsinized and resuspended at a concentration of $1.0-1.5 \times 10^{5}$ cells/ $\mathrm{m} l$. Aliquots of $200 \mu l$ were plated into microtitier wells along with ${ }^{3} \mathrm{H}$-Thymidine $(10 \mu \mathrm{Ci} /$ $\mathrm{m} l,{ }^{3} \mathrm{H}-\mathrm{TdR}$, New England Nuclear, Boston, MA.). After at least 24 hours, the medium was removed and the cells were washed in Hank's balanced salt solution. The following technique was utilized as described by Klagsbrun et al. ${ }^{91}$ in order to measure the incorporation of ${ }^{3} \mathrm{H} \cdot \mathrm{TdR}$. Each well was washed twice with $100 \%$ methanol for 4 minutes and then washed with $\mathrm{H}_{2} \mathrm{O}$. Cold $5 \%$ trichloroacetic acid was added twice for a period of 10 minutes and the wells were then washed 4 times with $\mathrm{H}_{2} \mathrm{O}$. The fixed cells were lysed with $150 \mu l$ of $0.3 \mathrm{~N} \mathrm{NaOH}$ and dissolved in $5.0 \mathrm{~m} l$ of scintillation cocktail. Radioactivity was measured by liquid scintillation counter.

\section{Results}

1) Characterization of Costal Cartilage Chondrocytes

The chondrocytes were plated into culture flasks at a concentration of $1.5 \times 10^{5}$ cells $/ \mathrm{m} l$ and reached confluence in 4-8 days maintaining a round or polygonal shape in high density areas. The medium was changed 1 to 2 times a week. The pattern of DNA synthesis in the first six days of culture is shown in Fig. 1. The rate of ${ }^{3} \mathrm{H}-\mathrm{TdR}$ incorporation increased markedly within the first four days after plating. The confluent grown chondrocytes stained with toluidine blue signified excellent ability of matrix synthesis (Fig. 2).

2) Effect of Separated Fractions on DNA Synthesis of the Condrocytes

The acid extracts of the cartilages were chromatographed on a Sephadex G 200 column eluted with $0.1 \mathrm{M}$ acetic acid. The proteins were eluted in four major components as shown in Fig. 3. Fractions corresponding to the peak were pooled as indicated. Each fraction was assayed for its effect on the proliferation of isolated chondrocytes in culture. Separated fractions were lyophilized and dissolved in Ham's F-12 medium. The protein concentration in the medium was adjusted to 1 to $10 \mathrm{mg} / \mathrm{m} l$. Incorporation of ${ }^{3} \mathrm{H}-\mathrm{TdR}$ into chondrocytes was affected by exposure to frac-

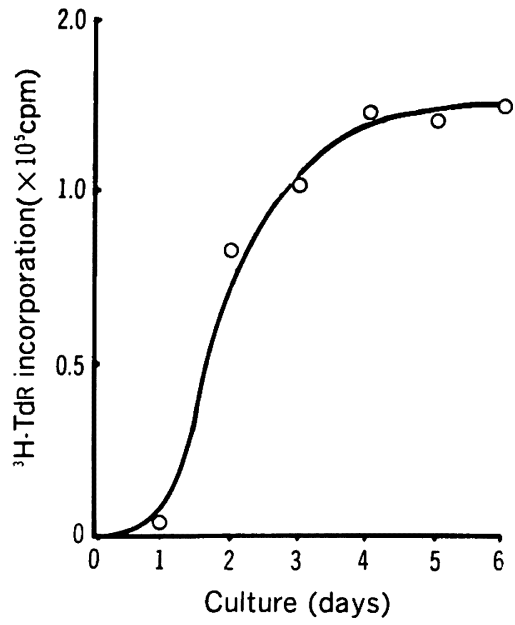

Fig. 1 "Growth curve" of the primary chondrocytes determined by ${ }^{3} \mathrm{H}-\mathrm{TdR}$ incorporation.

tions which were from mandibular condylar cartilage. Although higher molecular weight substances (F-I , F-II) had ability to accelerate the DNA synthesis of cultured chondrocytes, addition of the lower molecular weight fraction (F-IV) to primary cultures of chondrocytes obviously inhibited the ${ }^{3} \mathrm{H}-\mathrm{TdR}$ incorporation in comparison with control cells while no marked effect on ${ }^{3} \mathrm{H}-\mathrm{TdR}$ incorporation was observed with F-III (Fig. 4, Table 1).

The inhibitory effect of low molecular weight fractions from mandibular condylar cartilage was compared with those from other cartilage tissues, such as capital cartilage, chondroseptal cartilage and costal cartilage (Fig. 5). The relative inhibitory activity of the mandibular condylar cartilage extract was greater than those of the others. It was found that some quantity of inhibitory activities was present in the chondroseptum extract at the same concentration. The low molecular weight fractions of acid extract from capital cartilage and costal cartilage did not inhibit DNA synthesis in secondary cultured chondrocytes. The fraction from the mandibular condylar cartilage demonstrated the inhibitory effect in a concentration dependent manner as shown in Fig. 6. When the inhibitory substance was added to subcultured chondrocytes at different stages of cultivation, this inhibitory activity was gradually reduced according to 

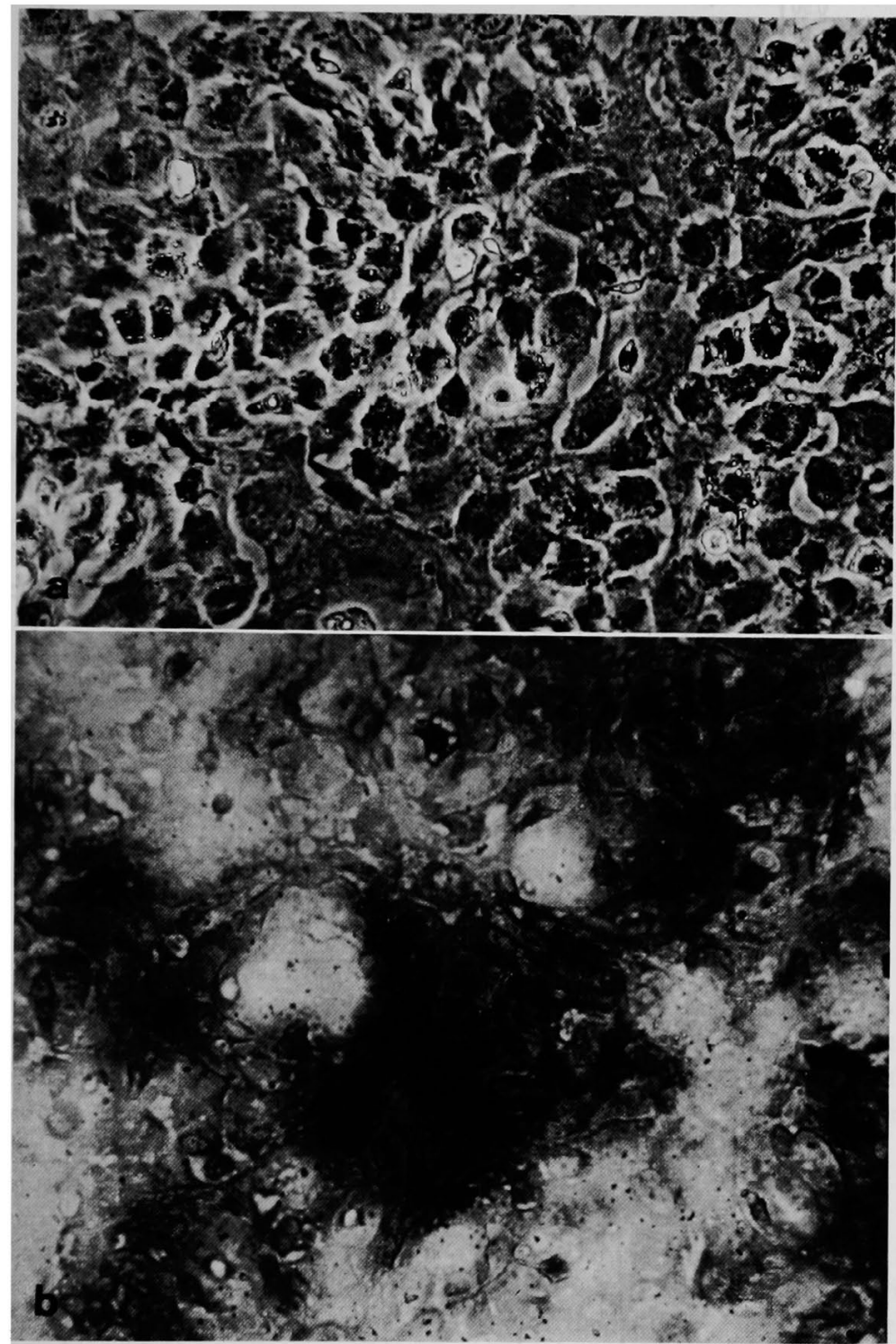

Fig. 2 a) Phase contrast photomicrograph of chondrocytes in seven days cultivation. These cells were plated at a concentration of $1.0 \times 10^{5}$ cells $/ \mathrm{m} l$ in $10 \%$ FCS containing Ham's F-12 medium. They maintained a round or polygonal shape $(\times 100)$. b) Matrix synthesis ability of the monolayered chondrocytes. Staining by toluidine blue $(\times 100)$.

subcultured progression. It is of interest that after about the fifth subcultured period, $80 \%$ of the inhibitory activities disappeared (Fig. 7).

3) SDS-PAGE

Growth inhibitory substance from the mandibular condyle was electrophoresed in order to examine its heterogeneity. An SDS-PAGE analysis indicated the presence of two major polypeptides. These apparent molecular weights were then estimated to be approximately 10,000 and 8,000 (Fig. 8). 

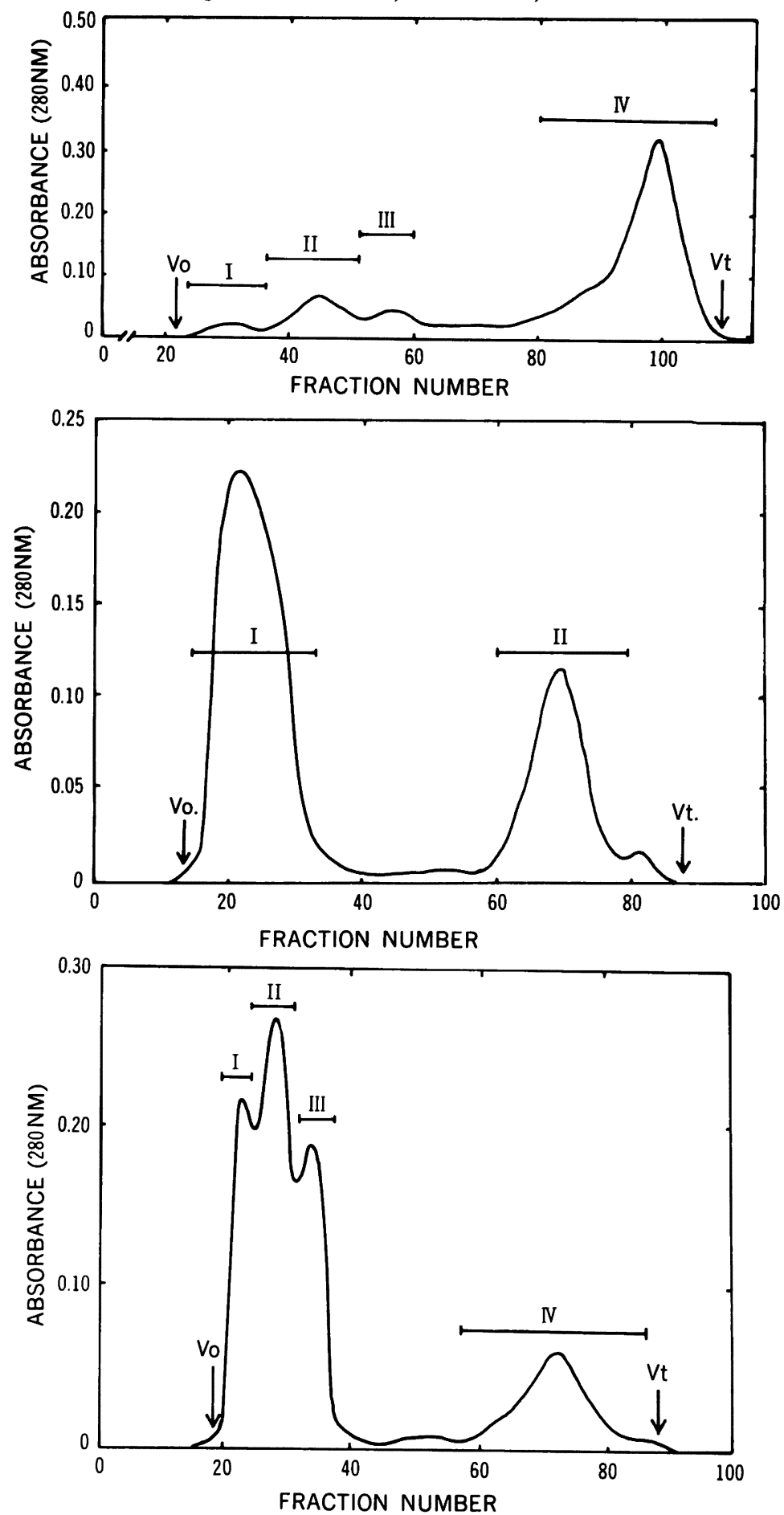

Fig. 3 Gel filtration of various different cartilage tissues extracts. a) Mandibular condylar cartilage b) Chondroseptum c) Costal cartilage These sample were chromatographed on Sephadex G $200(3 \times 100 \mathrm{~cm})$. Fractions were collected and monitored for absorbance at $280 \mathrm{~nm}$. They were separated into fractions indicated by bars. 


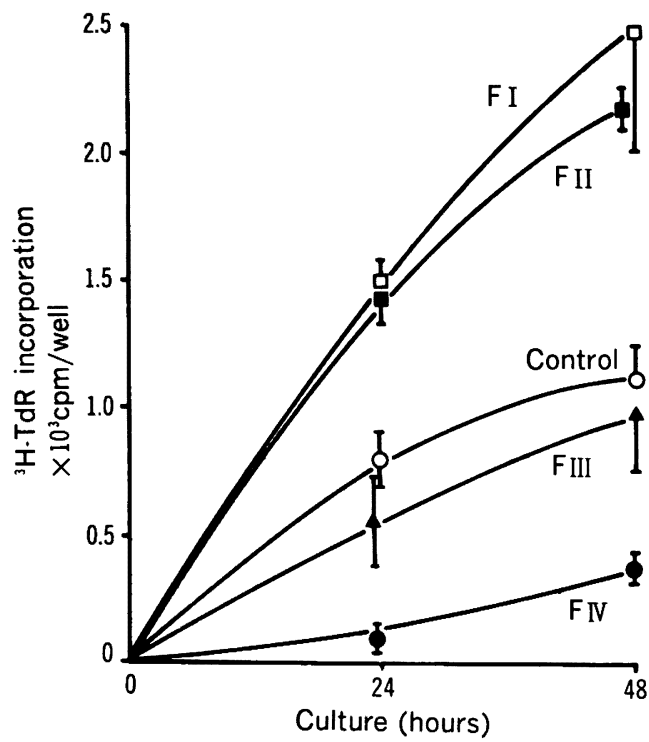

Fig. 4 Diversity of DNA synthesis in rabbit primary chondrocytes by separated extracts of mandibular condylar cartilage on ${ }^{3} \mathrm{H}-\mathrm{TdR}$ incorporation.

\section{Discussion}

The growth of condylar cartilage of the mandible is affected by many factors, such as growth hormones, steroid hormones and some local environmental factors ${ }^{13)}$. The influence on condylar growth exerted by the orthopaedic or orthodontic appliance is a very important problem not only in orthodontics but also other dental practices. One of the key point in mandibular growth regulation is at the level of cartilage cell proliferation. Petrovic et al. ${ }^{7}$ stated that when the condylar cartilage was

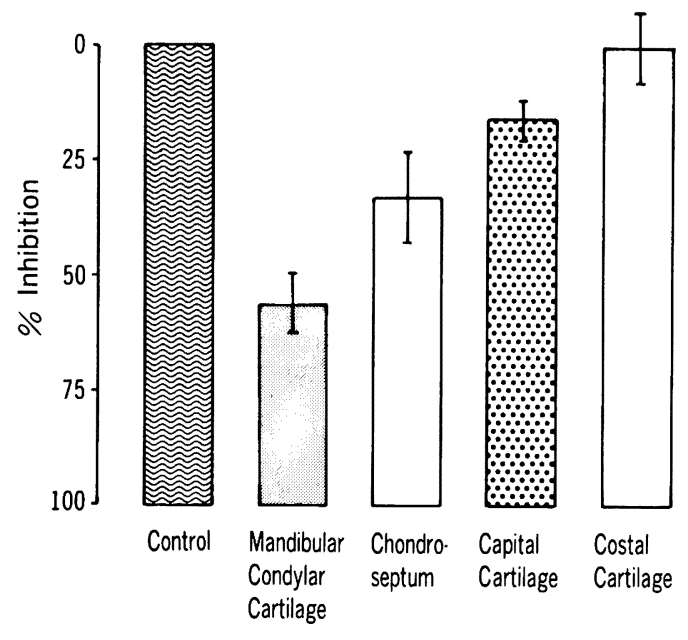

Fig. 5 The effect of low molecular weight fractions from mandibular condylar cartilage, chondroseptum and costal cartilage on ${ }^{3} \mathrm{H}-\mathrm{TdR}$ incorporation.

plated as an organ culture, the proliferation of prechondroblasts showed a lower growth rate. The results of a number of transplantation experiments seemingly showed a fundamental difference between epiphysial and synchondrotic cartilage.

The acid extract collected from rabbit mandibular condylar cartilage contained at least four fractions in the Sephadex G 200 chromatogram. Proliferation of chondrocytes was increased 2 times by exposure to the higher molecular weight fractions F-I and F-II (Fig. 4), while F-III had no effect. High molecular weight components like F. I and F-II, which are probably matrix components of cartilage tissue, can provide an excellent

Table 1

\begin{tabular}{lllll}
\hline & \multicolumn{3}{c}{${ }^{8} \mathrm{H}-\mathrm{TdR}$} & incorporation $\left(\times 10^{3} \mathrm{cpm} /\right.$ well $)$ \\
\cline { 2 - 5 } & $\begin{array}{l}\text { 24 hours } \\
\text { culture }\end{array}$ & T/C & $\begin{array}{l}48 \text { hours } \\
\text { culture }\end{array}$ & $\mathrm{T} / \mathrm{C}$ \\
\hline Control & $0.81 \pm 0.12$ & & $1.15 \pm 0.19$ & \\
F I & $1.50 \pm 0.08^{*}$ & 1.85 & $2.49 \pm 0.53^{*}$ & 3.17 \\
F II & $1.39 \pm \ldots 11^{*}$ & 1.71 & $2.26 \pm 0.13^{*}$ & 1.97 \\
F III & $0.56 \pm 0.21$ & 0.69 & $1.01 \pm 0.34$ & 0.87 \\
F IV & $0.12 \pm 0.05^{*}$ & 0.15 & $0.19 \pm 0.04^{*}$ & 0.17 \\
\hline
\end{tabular}

* Significantly different from Control, $\mathrm{p}<0.001$ 


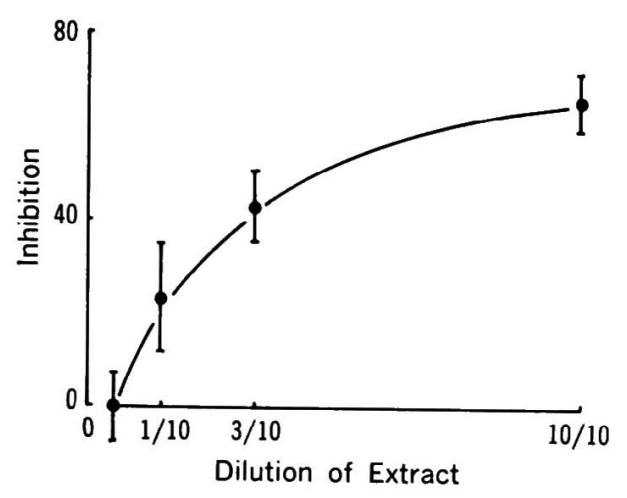

Fig. 6 Concentration dependent effect of the low molecular weight fraction from mandibular condylar cartilage on ${ }^{3} \mathrm{H}-\mathrm{TdR}$ incorporation.

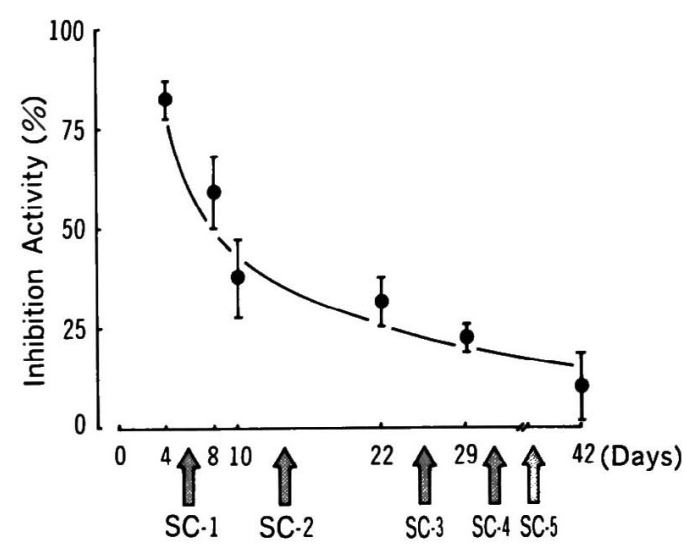

Fig. 7 The changing of the effect of inhibitory substance accoding to the subcultured periods.

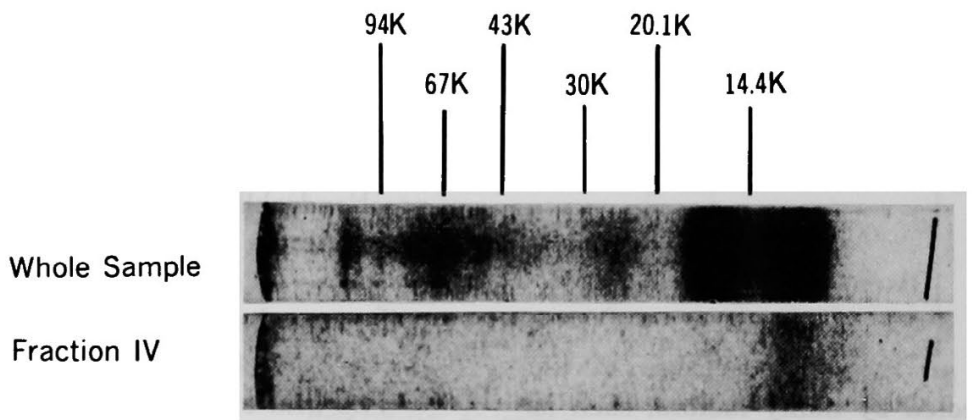

Fig. 8 SDS-PAGE gel electrophresis of the acid extract from mandibular condylar cartilage.

environment for cell proliferation. On the other hand, as can be seen in Fig. 4, addition of F-IV to the cells markedly inhibited the thymidine incorporation after 24 hours (17\% of control). These results demonstrate that there is an inhibitory substance as well as stimulatory factors in the growth regulation mechanism of mandibular condylar cartilage. The best known inhibitors of cell proliferation are chalones, originally defined as substance which maintained tissue homeostasis by inhibition of cellular mitosis ${ }^{13)}$. They were stated to be non-cytotoxic, tissue specific and species non-specific. In order to determine whether inhibitory factors like chalones are present in various cartilages (chondroseptum, capital cartilage and costal cartilage), extracts from the cartilages were compared with the mandibular cartilage. Only mandibular condylar cartilage had a growth inhibition factor which was not found in other epiphyseal cartilages. Thus, the fundamental difference of growth activity in this tissue may depend upon the existance of this growth inhibiting substance.

The reduction of growth inhibitory activity of the condylar cartilage extract (F-IV), according to the subculture sequence (Fig. 7) suggest that the nature of the target cells was gradually altered during their subculture due to a loss of the receptor on the cell membrane by dedifferentiation process. This speculation, however, is contradictory to the principle of cell biology. In endochondral bone growth, chondrocytes cannot proliferates without undergoing dedifferentiation. Only undifferentiated mesenchymal cells can proliferate by cell division and develop into prechondrocytes. For identification of proliferation of chondrocytes, the following conditions should be taken into account. 1) What was the number of 
undifferentiated mesemchymal cells present in the cartilage culture when the growth accelerated agent was added to it? 2) Whether the number of undifferentiated mesenchymal cells were increased or decreased at a certain period of time after the agent was added to the culture? If one can find the mesenchymal cells were decreased in number under the latter condition, no further cell proliferation would occur. On the contrary in case of increase in the number of mesenchymal cells further cell proliferation should take place, the proliferated cells eventually could develop into prechondrocytes.

Recently many growth factors, such as fibroblast growth factor (FGF), epidermal growth factor (EGF), and cartilage derived factor (CDF), have been isolated and well characterized ${ }^{10-12}$. These growth factors range in molecular weight from approximately 5,000 to 10,000 . The growth inhibitory factor derived from condylar cartilage appears to be a protein of relatively low molecular weight, which is similar to the molecular weight of the growth factors, but opposite in action. The identification of the growth inhibitory factor in the mandibular condyle shows a presence of unique growth control mechanism in this tissue. Whether this unique growth inhibitory factor has a functional role not only in cellular proliferation but also in cellular metabolism needs investigation to understand mechanism of the growth control.

\section{Conclusions}

An inhibitory factor was found to be uniquely presen tin the mandibular condylar cartilage, and although a slight inhibitory activity was found in chondroseptum, no effect of inhibition on ${ }^{3} \mathrm{H}-\mathrm{TdR}$ incorporation of cultured chondrocytes in other cartilages. It is still unknown whether the growth inhibitory factor found in mandibular condylar cartilage has any physiological role in vitro. Since the inhibitory factor is only in the mandibular condylar cartilage, it is possible that this factor constitutes part of the local growth regulating. mechanism.

\section{Acknowledgement}

I am obliged to professor Yoshii Suzuki, department of orthodontics, and professor Shigeru Saito, department of oral biochemistry for giving me helpful advice. I am also grateful for many valuable discussions from the following: Dr. Hironori Kitamura, department of oral histology, Dr. Margaret W. Neuman, department of oral biochemistry, Dr. Masazumi Ooshita, department of orthodontics, Dr. Donald M. Brunette, and Dr. Leon Kraintz, associate professor and professor of the department of oral biology, University of British Columbia. Finally, I gratefully acknowledge useful suggestions during this work by Dr. Sadao Sato, and the colleagues of the department of orthodontics, Kanagawa Dental College.

抄録：下額骨の成長発育は主として下顎頭部の軟骨性化骨により進行することは良く知られている が，その様相は極めて複雑である。そこでそれを物質レベルで解明する目的で以下の実験を行った。

日本白色家鬼75羽より下頢頭軟骨を単離し $0.1 \mathrm{M}$ 酢酸で homogenize 後, 抽出物質に対して Sephadex G200による Gel chromatography を行った。得られた4つのピーク物質を, 通法にしたがい初代培荃 された家鬼肋軟骨培養系に添加し ${ }^{8} \mathrm{H}$-Thymidine の取り込み能に与える影響を検索した。

その結果, 抽出物中の低分子分画物質, すなわち分子量約 10,000 の蛋白に, 培養軟骨細胞の DNA 合 成能を著しく抑制する効果が認められた。一方, 他の軟骨組織, すなわち大䛧骨関節頭軟骨, 肋軟骨, 鼻中隔軟骨から同様の方法で抽出された低分子分画物質には，鼻中隔軟骨由来の物質に若干の 抑制効果 を認めたのみで，他の軟骨由来の物質には有意な効果は認められなかった。したがってこの物質は組織 特異的に存在していることが確認された。またこの抑制効果は bioassay に供する軟骨細胞の性質によ り変化した。すなわち長期にわたり継代を繰り返すほど効果が低減する傾向が認められた。その理由と して細胞の脱化分による receptor の継時的変化, あるいは培養系に cell selection が生じた可能性が 示唆された。

以上のことから下䫓頭軟骨には軟骨細胞の分裂を抑制する物質が存在し，これが関節軟骨の成長を調 節している可能性が強く示唆された。 


\section{References}

1) Rushton, M. A.: Growth at the mandibular condyle in relation to some deformities. $\mathrm{Br}$. Dent. J. 76 : 57-68, 1944.

2) Sarnat, B. G. and Muchnic, H. : Facial skeletal changes after mandibular condylectomy in the adult monkey. J. Anat. $108: 323-338$, 1971.

3) Sarnat, B. G. and Wevler, M. R.: Growth potential of transplanted resection of septal cartilage in the rabbit. Am. J. Anat. 188 : 755-760, 1966.

4) Kosk, K. and Ronning, O.: Growth potential of transplanted components of the man. dibular ramus of the rat. III. Soum. Hammaslaak Seur. Toim. 61 : 292-297, 1965.

5) Kosk, K. and Ronning, O.: Growth potential of intracerebrally transplanted cranial base synchondrosis in the rat. Archs. Oral Biol. 15 : 1107-1108, 1970.

6) Petrovic, A.: Control of postnatal growth of secondary cartilage of the mandibule by the mechanism regulating occlusion cybanetic model. Transaction of Europian Orthodontic Society. 15 : 69-75, 1974.

7) Statzman, J and Petrovic, A.: Intrinsic re- gulation of the condylar cartilage growth rate. Europ. J. Orthod. 1 : 41-54, 1979.

8) Suzuki, F., Yoneda, T. and Shimomura, Y. : Calcitonin and parathyroid hormone stimulation of acid mucopolysaccharide synthesis in cultured chondrocytes isolated from growth cartilage. FEBS Lett. 70 : 155, 1976.

9) Kragsbrun, M., Langer, R., Levenson, R. and Smith, S.: The stimulation of DNA synthesis and cell division in chondrocytes and 3T3 cells by a growth factor isolated from cartilage. Exp. Cell Res. 105 : 99-108, 1977.

10) Gospodarowich, D. : Purification of fibroblast growth factor from bovine pituitary. J. Biol. Chem. 250 : 2515-2520, 1975.

11) Cohen, S. and Carpenter, G. : Human epidermal growth factor; Isolation and chemical biological properties. Proc. Natl. Acad. Sci. USA. 72 : 1317-1320, 1975.

12) Kato. Y.: Somatomedine-like peptide(s) isolated from fetal bovine cartilage (Cartilage Derived Factor); Isolation and some properties. Proc. Natl. Acad. Sci. USA. $11: 6831-$ 6835,1981

13) Bullough, W. S.: The control of mitotic activity in adult mammalian tissues. Biol. Rev 37 : 307-312, 1962. 